\title{
Arbor
}

\section{Algunas reflexiones sobre el teatro breve del Siglo de Oro y la Postmodernidad}

\author{
Javier Huerta Calvo
}

Arbor CLXXVII, 699-700 (Marzo-Abril 2004), 475-495 pp.

La modesta tesis que intentará defender este articulo es que el gran impulso que los géneros menores han experimentado en los últimos veinticinco años, sobre todo en la crítica pero también en la práctica escénica, es consecuencia, en buena parte, del clima cultural derivado de la postmodernidad. La coincidencia de ciertos hechos artísticos, culturales, literarios y hasta políticos ha sido determinante para que el canon teatral del Siglo de Oro, antaño demasiado condicionado por factores morales y religiosos, se haya abierto a partir de los años ochenta al gusto más heterodoxo con que, en mi opinión, han de ser evaluadas las formas del teatro breve, sobre todo a partir del descubrimiento de Bajtín. La Filología, aunque en menor medida que otras áreas del conocimiento, también se ha dejado contaminar por estas «otras» miradas de la différance postmoderna. Ello afecta a la literatura en general, pero de modo particular a un teatro como el breve que rebosa elementos eróticos, escatológicos, inmorales, irrespetuosos y transgresores, cuya exégesis, y no digamos su explicación en las aulas, resultaba harto dificil durante la larga Cuaresma del franquismo ${ }^{1}$.

\section{Redescubrir el teatro breve}

De pedírsenos seleccionar, como paradigmática -objetiva y subjetivamente- de una historia del gusto, una sola obra del teatro breve de los si- 
glos de oro, elegiríamos sin duda El retablo de las maravillas, de Cervantes. Por varias razones: el tratamiento originalísimo que imprime el autor a una materia de tanta solera folclórica, como es la del «engaño a los ojos»; la impecable e implacable máquina de la burla que pone en juego, al servicio de una ideología muy crítica con el poder establecido; el hecho de que los personajes activos de la burla provengan del mundo del teatro, en lo que se nos antoja una insinuación muy clara acerca del poder del teatro para desvelar la mentira social; la alegoría satírica aplicada al pequeño mundo de Tontonela, microcosmos de la España del siglo XVII y aun de cualquier otra sociedad, pues que el ingenio del autor nunca se pierde en localismos costumbristas; su fascinante lenguaje, volcado en una prosa moderna y en un brillante diálogo, que contrasta con el artificio de tanto verso huero y hueco de la comedia barroca; la gran fortuna, en fin, de este entremés, que ha merecido imitaciones y reescrituras diversas a través de los tiempos, hasta llegar lozanísima a nuestros días, como lo demuestran los nombres de Rafael Dieste, Manuel Altolaguirre, Lauro Olmo, Jacques Prévert, Bertolt Brecht, Jerónimo López Mozo o Albert Boadella. Todas estas circunstancias hacen del entremés cervantino una auténtica obra maestra, comparable -pese a su brevedad- en forma y trascendencia a cualquiera de nuestros grandes dramas de la misma época.

Sin embargo, la genialidad de El retablo de las maravillas no es un hecho aislado ni puede explicarse sin tener en cuenta la rica tradición que lo sustenta: esos centenares de piezas que conforman el riquísimo corpus del teatro breve del siglo XVII y que parecen reclamar un tratamiento más colectivo que singularizado. Por otro lado, cualquier buen aficionado al arte dramático podría señalar media docena de piezas antológicas más, habituales desde hace mucho tiempo en los repertorios de compañías tanto profesionales como universitarias: así, alguno de los divertidos pasos de Lope de Rueda, como el que hace el número $\mathrm{V}$ de $E l d e$ leitoso, conocido desde Moratín como La tierra de Jauja; el anónimo de La cárcel de Sevilla, atribuido en más de una ocasión a Cervantes; alguno de los muchos dedicados a la figura del carismático actor que fuera Juan Rana, debidos a la pluma de Luis Quiñones de Benavente, Agustín Moreto o Jerónimo de Cáncer; la mojiganga de Las visiones de la muerte, de Calderón de la Barca, y, desde luego, cualquiera de los otros siete entremeses de Cervantes. Con éstas y otras piezas, hoy por fortuna más accesibles a los lectores, bien podríamos trazar el mapa de la dramática menor áurea, que tendría como puntos capitales algunos de los temas que más interesan a los dramaturgos y a los espectadores de esta época a la que llaman posmoderna, a saber: el relativismo axiológico, la liber- 


\section{Algunas reflexiones sobre el teatro breve...}

tad de costumbres, la mentalidad hedonista, el predominio del juego y la metaficción, la aceptación de la ambigüedad como normal modo de comportamiento, la atracción por el «otro», la marginalidad y la diferencia, el papel cada vez más relevante de la mujer, la visión fragmentaria del mundo... ${ }^{2}$. Ni mucho menos estoy queriendo afirmar con ello el imposible histórico de que el teatro breve sea postmoderno, sino que presenta rasgos coincidentes con ciertas tendencias de la modernidad y aun de la postmodernidad. En suma, que la lectura y la representación de estas obrillas consuenan bien con los gustos de la cultura de hoy en día, decididamente inclinada del lado dionisíaco de la existencia, por decirlo con expresión del filósofo que los historiadores consideran padre y mentor de la postmodernidad, el alemán Friedrich Nietzsche ${ }^{3}$.

Una mirada a la bibliografía publicada en los últimos años, y que en este mismo número repasa con su rigor acostumbrado Abraham $\mathrm{Ma}$ droñal, no viene sino a corroborar aún más el paralelismo que advertimos entre teatro breve y cultura postmoderna. Quiero decir que el auge crítico e historiográfico de los géneros menores viene a coincidir cronológicamente con la entrada en España de los vientos de la postmodernidad, aproximadamente hacia 1981. Antes de esta emblemática fecha sobran dedos de la mano para enumerar las estudiosos que tuvieron a bien ocuparse de estos géneros, tradicionalmente preteridos, cuando no olvidados, del canon teatral clásico ${ }^{4}$ : el pionero Cotarelo y Mori con su monumental Colección de entremeses, loas, bailes, jácaras y mojigangas (1911), los hispanistas Hannah E. Bergman, estudiosa de Quiñones de Benavente, y Henri Recoules, y, sobre todo, el maestro Asensio del Itinerario del entremés (1965). Por el contrario, a partir de 1981 los dedos -por seguir con la misma imagen- se nos hacen huéspedes, pues que son incontables los investigadores que, desde todas las perspectivas, se han consagrado a la exploración del que en otro lugar he llamado «el gran mundo del teatro breve» ${ }^{5}$.

Ciertamente, el año de marras presenta connotaciones muy significativas en varios órdenes: en el político, 1981 ocupa el centro mismo de la transición a la democracia; en el cultural, inicia la década, relativamente prodigiosa -tampoco es cuestión de exagerar- de los ochenta, con el fenómeno de la movida madrileña, acaudillada por ese alcalde no poco carnavalesco que fuera don Enrique Tierno Galván; y en el literario, en fin -que es ahora el que nos interesa- , es el del centenario de Calderón de la Barca, que permitió descubrir, mediante el memorable Congreso organizado por Luciano García Lorenzo, al Calderón lúdico, festivo y hasta transgresor que las apologías románticas y, desde luego, las franquistas habían venido ocultando o minimizando ${ }^{6}$. Pienso que en la mayoría de los 
historiadores modernos de Calderón y del teatro áureo pesaba más la influencia de Heráclito que de Demócrito, cuando -como es sabido y demuestra en un precioso trabajo Aurora Egido ${ }^{7}$ - en la época ambas actitudes estaban equilibradas en el imaginario cultural. Una de las aportaciones mayores de la crítica postmoderna es haber vuelto a recuperar ese bifrontismo, sobre el cual escribiera páginas memorables el recién fallecido Vittore Branca a propósito de la capacidad de Boccacio y de otros autores medievales y clásicos por conciliar en su obra lo serio y lo cómico $^{8}$. No es casual, por otro lado, que este revival de la literatura festiva -alentado desde Francia, en lo que se refiere al hispanismo, por algún vir doctus et facetus como Robert Jammes- se viera acompañado por el gran éxito alcanzado por uno de los libros más emblemáticos de la postmodernidad: Il nome della rosa, de Umberto Eco, donde entre burlas y veras se sometía a burla inteligente alguno de los sistemas que la crítica había entronizado y sacralizado hasta el exceso ${ }^{9}$. Que lo hiciera uno de los paladines de la Semiótica venía a rubricar el nuevo talante -irónico y distanciador- con que podían y debían ser examinados los hechos culturales, máxime si éstos tocaban a un terreno tan sensible a la risa como el teatro ${ }^{10}$.

Al mencionado Congreso calderoniano están vinculados muchos de los críticos e historiadores que, a partir de ese momento, mayor atención concedieron a las formas del teatro breve. Baste citar los nombres del activo ñaque investigador que por entonces formaban Evangelina Rodríguez y Antonio Tordera, y en los cuales representamos el espíritu de la que -si no fuera por el descrédito en que han caído hoy las teorías generacionales- me atrevería a llamar «generación crítica de 1981». Una generación que, como mandan los cánones, hasta tuvo un líder espiritual en la figura del teórico ruso Mijaíl Bajtín. Las tesis de este autor acerca del Carnaval, conocidas en los países occidentales muy tardíamente por culpa de la persecución de la que fuera objeto durante los duros años del estalinismo, suministraron la cimentación teórica suficiente para interpretar el complejo mundo farsesco del teatro breve. La divulgación de sus excepcionales escritos, ninguneados todavía por alguno de nuestros filólogos a la violeta, coincidió con este resurgir postmoderno. Frente a los sistemas críticos que, cada uno por su parte, habían levantado los formalismos más o menos cartesianos y los sociologismos más que menos marxistas, la obra de Bajtín abdicaba -siguiendo el ejemplo de Nietzsche- de las pretensiones sistemáticas y totalizadoras para ofrecer una visión renovada y problemática de la literatura que tuvo la virtud de enamorarnos a muchos ${ }^{11}$. Que la recepción española del mayor pensador literario del siglo XX -Todorov dixit-corriera parejas con el final de esa 
larga Cuaresma que fue el franquismo es otra coincidencia venturosa más que coadyuva a explicar la gran moda de nuestros géneros dentro de un contexto cada vez más favorable ${ }^{12}$.

Quizás la imagen de la batalla que protagonizaron las dos fuerzas antagónicas, bien que complementarias, de Carnaval y Cuaresma -que tanto ha atraído a dramaturgos de todos los tiempos, desde Juan del Encina a José Luis Alonso de Santos- explica mejor que ninguna otra la dialéctica entre teatro mayor y menor, entre comedia y entremés en los siglos de oro; una dialéctica de difícil resolución; para muchos, una falsa dialéctica que sólo viene a rubricar la neutralidad ideológica de la fiesta teatral, una estructura que, a mi modo de ver, no admite una perspectiva uniformizadora y simplista sino que anuncia la perplejidad de la visión fragmentaria postmoderna. En un largo, denso e inteligente ensayo sobre la recepción del Calderón entremesista, publicado bajo el título de «La sonrisa de Menipo»13, Evangelina Rodríguez hubo de desplegar toda su fuerza dialéctica para rebatir los a veces temerarios juicios de Antonio Regalado, en su por otra parte notabilísima monografía sobre Calderón (Calderón y los orígenes de la modernidad, 1995), acerca de la naturaleza inofensiva del entremés, cuya fachada de género inconformista no hace, en opinión de Regalado, sino encubrir un mensaje profundamente conservador. Es, en efecto, ya cansado tener que alegar las diatribas de teólogos y moralistas en contra del entremés para testimoniar su naturaleza inconformista. El entremés es una forma opuesta, tanto en significante como en significado, a la comedia. Su genealogía es plenamente carnavalesca, en la acepción más bajtiniana del término. Como género dramático, su puesto es equivalente al de la farsa europea, cuya dimensión revulsiva y hasta subversiva es indiscutible. Creo, en fin, que cuando Regalado y otros críticos cuestionan el mensaje crítico del teatro breve, están pensando bajo unos parámetros similares a quienes en los años sesenta defendían la teoría sartriana del engagement. Es obvio que ese tipo de compromiso, que encontramos en el teatro épico de Brecht o en los dramas sociales de Alfonso Sastre, no ha de buscarse en el entremés, ni falta que le hace, añadiríamos nosotros.

A mi juicio, la oposición entre comedia y entremés no puede ser entendida como una verdadera lucha de opuestos entre un género acomodaticio al sistema político, tal como lo caracterizara José Antonio Maravall en La cultura del Barroco (1975), y un género respondón y contestatario. Esta simplista oposición, en la que muchos caímos a fines de los setenta, era propia del maniqueísmo ideológico de esos años, y queda muy bien reflejada en la ponencia que Agustín García Calvo presentara en las Jornadas de Almagro de 1978, a la que -en consonancia con 


\section{Javier Huerta Calvo}

sus tesis incendiarias- puso el título de «Propuesta de un auto de fe para el teatro español del Siglo de Oro»; auto de fe del que sólo salvaba, precisamente, al teatro breve ${ }^{14}$. Estas opiniones en contra de la comedia y, sobre todo, a favor del entremés eran bastante comunes en los dramaturgos de entonces, como Antonio Gala, Lauro Olmo, Francisco Nieva y Miguel Romero Esteo ${ }^{15}$. Pero, si se nos permite el chiste, ni tanto ni tan calvo. La comedia barroca contiene innumerables elementos críticos que siguen interesando al espectador de hoy, como lo demuestra el repertorio, cada vez más amplio, de la Compañía Nacional de Teatro Clásico (CNTC), en el cual, al lado de obras bien instaladas desde siempre en el canon, se han programado otras, que han sido auténticas sorpresas, como Antes que todo es mi dama, La gran sultana, La venganza de Tamar o la que acabamos de admirar en la temporada 2003-04, La serrana de la Vera, una tragedia límite no fácilmente reductible a los esquemas sociologistas que proliferaron por entonces y que ya sólo aducen algunas vieja glorias de la crítica teatral periodística, eso sí, con notable influencia en la determinación del gusto de muchos espectadores.

Pese a todo, el entremés del siglo XVI, como en general todo el teatro de esta época, ofrece una carga crítica de superior entidad a la del entremés barroco. Las provocadoras intervenciones de los villanos bufonescos en los introitos de Torres Naharro, los chistes groseramente escatológicos que inundan los autos y las farsas primitivos, el descaro boccaccesco al abordar asuntos amatorios de ciertos entremeses de la época de Felipe II, dibujan un panorama algo distinto al del entremés barroco, más sofisticado a un nivel formal pero ideológicamente más domesticado. Es, por eso, por lo que no es inoportuno hablar de dos etapas en la historia del entremés. Una primera, vinculada a este periodo criticista, que tiene su punto culminante en los Ocho entremeses publicados en 1615 por Cervantes, y una segunda etapa, en la cual el entremés y demás formas análogas van siendo absorbidas cada vez más por la comedia, llegándose a contagiar de su lenguaje -el verso, la espectacularidad-e, incluso, de su visión del mundo cortesana. Pero tanto en una como en otra etapa el teatro breve manifiesta una frescura inaudita, que lo ha convertido en el eje que atraviesa toda la historia del teatro español, pues que no se da otro género con tal capacidad de pervivencia y de transformación a través de los siglos. La genealogía de las formas breves constituye el árbol más frondoso de la historia del teatro español: con un tronco común que echa sus raíces en ritos y espectáculos farsescos de la Edad Media -juegos de escarnio, cencerradas, mascaradas- asociados a la fiesta de fiestas, el Carnaval ${ }^{16}$, y con ramas principales y secundarias por las que discurre la savia de formas viejas y renovadas como son 
Algunas reflexiones sobre el teatro breve...

el entremés, el paso, la loa, el baile, la jácara, la mojiganga, el fin de fiesta, el sainete, la tonadilla, el sainete lírico, el género chico, el monólogo, el apropósito, el pasillo... ${ }^{17}$. Encargados de dar contenido a estas formas variadas los autores más destacados de la historia del teatro: Juan del Encina, Lope de Rueda, Miguel de Cervantes, Luis Vélez de Guevara, Francisco de Quevedo, Luis Quiñones de Benavente, Jerónimo de Cáncer, Pedro Calderón de la Barca, Antonio de Zamora, Diego de Torres Villarroel, Juan Ignacio González del Castillo, Ramón de la Cruz, Manuel Bretón de los Herreros, Ricardo de la Vega, José López Silva, Vital Aza, Carlos Arniches, Serafín y Joaquín Álvarez Quintero, Enrique García Álvarez, Pedro Muñoz Seca, Jacinto Benavente, Ramón del Valle-Inclán, Federico García Lorca, Alejandro Casona, Rafael Dieste, Max Aub, José María Rodríguez Méndez, Lauro Olmo, Francisco Nieva... ${ }^{18}$.

Me he entretenido en referir esta nómina abundosa para mostrarle al lector que, si la consideración crítica de nuestros géneros ha tenido sus momentos bajos hasta la gran eclosión de 1981, la estima de los creadores y de los espectadores, que son -no lo olvidemos- quienes forman la historia del gusto, y no los críticos, ha sido constante con el paso del tiempo, inclusive en la época del despotismo escénico de la Ilustración, en la cual el teatro breve, a pesar de cortapisas y hasta de prohibiciones, se mantuvo con una vitalidad mayor que en la centuria anterior. Después, debió ser la publicación en la Biblioteca de Autores Españoles, a mediados del siglo XIX, de los entremeses y jácaras de Calderón por parte de Juan Eugenio Hartzenbusch lo que impulsara a muchos directores y actores a incluir entremeses como La rabia o El dragoncillo en sus repertorios. En varias funciones de la época, en las que venía manteniéndose una estructura parecida a la de la fiesta teatral del Siglo de Oro, podemos ver esta alternancia de obra mayor o seria y piezas menores ${ }^{19}$. Un interesante número de la colección «La Farsa» del año 1933 se publicó bajo el título de La fiesta del entremés y en él se recogían los «trabajos leídos y representados por primera vez en el festival que, a beneficio del Montepío de Autores Españoles, se celebró en el Teatro Cómico de Madrid el día 14 de diciembre de $1932^{20}$. Este curioso tomito va precedido, a manera de prólogo, de una «conferencia jocoseria de El licenciado Tijeras» encarnado a la sazón por el gran actor cómico Enrique Chicote, cuyo papel en la evolución del sainete contemporáneo es homologable al que desempeñó Cosme Pérez respecto del entremés tres siglos antes. El texto del enigmático licenciado Tijeras venía a resumir las ideas de don Emilio Cotarelo y Mori en su «Estudio preliminar» a la Colección de entremeses, loas, bailes, jácaras y mojigangas (1911), al tiempo que se apoyaba en juicios favorables de otros críticos de entonces, como el siempre 


\section{Javier Huerta Calvo}

exigente Ramón Pérez de Ayala, para quien «en arte no hay género grande ni género chico", pues "eso de cotizar -sentenciaba- las obras de arte por la alzada y el peso es cosa de chalanes o tratantes de ganado»; o el no menos exigente Clarín, que a propósito del estreno de un entremés de los hermanos Álvarez Quintero, titulado El ojito derecho, que trata sobre la venta de un burro entre gitanos, afirmaba categórico: «Prefiero El ojito derecho con burro que no habla, a muchos dramas con tesis que rebuznan». Al igual que en tantas otras ocasiones, Clarín daba con el quid de la cuestión, pues el género chico sirvió, entre otras cosas, para aligerar y renovar la escena de su tiempo, tan cargada de los espesos dramas neorrománticos, con un lenguaje innovador, de cuya frescura se haría eco nada menos que Rubén Darío en el «Prólogo» de Cantos de vida y esperanza.

El divertido programa de esta Fiesta del entremés constaba en cuanto a piezas representadas de La salsa de los caracoles, «apunte de sainete» de Francisco Serrano Anguita; Visita de prueba, "paso de comedia» de Serafín y Joaquín Álvarez Quintero, El aguaducho, «entremés en prosa» de Federico Romero y Guillermo Fernández Shaw, con un número musical de Federico Moreno Torroba, y Ni contigo ni sin ti, otro «entremés en prosa» de Antonio Ramos Martín. Como se ve, más que una fiesta teatral a la manera del siglo XVII, lo que tenemos es una moderna reactualización de una de las formas de representación sobre la que menos sabemos de nuestra época áurea, esto es, la folla de entremeses. Desde hace algunos años ese gran director que es Ángel Gutiérrez viene programando en su teatrito de cámara «Anton Chéjov» funciones parecidas a las follas, en las que alternan los pasos de Lope de Rueda y los entremeses de Cervantes con sainetes de Arniches y los hermanos Quintero, en una hermosa manera de aunar la risa entremesil de la Edad de Oro y con la de la Edad de Plata.

Esta tradición casticista, que gira en torno al sainete, ha ido paralela con otra tradición de más amplio vuelo, que tiene en el entremés clásico su punto de referencia, y que está en el centro mismo de ese fenómeno tan importante para la regeneración de la escena contemporánea que fue la llamada «reteatralización». Los títulos más importantes de este primer tercio del siglo, desde el Teatro fantástico (1892), de Benavente, a los esperpentos de Valle y las farsas de Lorca, deben gran parte de su originalidad a su huida del modo naturalista y su deseo de renovar el teatro a partir de formas tradicionales: la comedia del arte, el teatro de títeres, el entremés, la pantomima, la farsa carnavalesca... ${ }^{21}$. Y esto no sólo ocurrió en el nivel de la creación sino también en el de la práctica escénica, como 
Algunas reflexiones sobre el teatro breve...

demuestran los dos grupos más importantes de teatro no comercial de la Segunda República: «La Barraca» y el «Teatro del Pueblo» de las Misiones Pedagógicas. En «La Barraca», junto a los consabidos dramas de honor (Fuente Ovejuna, El burlador de Sevilla) o los autos. sacramentales (La vida es sueño) no faltaron los entremeses: La cueva de Salamanca, La guarda cuidadosa, Los dos habladores y El retablo de las maravillas; el paso de Rueda, La tierra de Jauja, era representado al final de Fuente Ovejuna. Aunque en ocasiones estas representaciones llevaban figurines y decorados tan maravillosos e historiados como los que realizaran Manuel Ángeles Ortiz, lo normal, tal como nos testimonia Luis Sáenz de la Calzada, es que la representación se hiciera a palo seco, pues los entremeses son, en el fondo, una forma de teatro povero, donde la fuerza de la palabra, de la gestualidad y del movimiento no precisan de una decoración muy espectacular. Eso sí, los textos de los entremeses no necesitaban de tanto retoque y manipulación como los de las comedias (pensemos de nuevo en el final truncado de Fuente Ovejuna en la versión lorquiana), pues para Lorca conectaban como ninguna otra forma con la sensibilidad popular. A propósito del espectáculo que formara a base de La cueva de Salamanca, La guarda cuidadosa y Los dos habladores decía el poeta:

Estas tres obritas son tres joyas en las que se nota la maestría del poeta, que trabaja con alegría y con altura, es decir, dominando el tema. Esta sensación de dominio, de caliente frialdad, la tiene Cervantes como la tiene Goethe. Es la facultad de ir guiando los asuntos por una cauce previsto sin que jamás falte el temblor misterioso de lo inspirado. [...] Y desde luego no es arqueológico, no es viejo, no está pasado. Estos entremeses están vivos, como acabados de hacer, y yo he visto su efecto siempre despierto en los públicos de aldeas y ciudades. Trama y lenguaje de farsa humana eterna... ${ }^{22}$.

La misma apreciación del entremés como forma de teatro didáctico al servicio de unos ideales reformistas es la que se observa en el programa de las «Misiones Pedagógicas», en el que, además de los pasos de Lope de Rueda y los entremeses de Cervantes, hay que poner las reescrituras tan interesantes que llevó a cabo Casona, como el Entremés de Sancho Panza en la Ínsula Barataria, luego recopiladas en su precioso Retablo jovial. Estas aventuras de teatro ambulante, que concedieron al teatro breve tal importancia, están vinculadas a un objetivo utópico ${ }^{23}$, por desgracia frustrado por la Guerra Civil, en cuyo transcurso, pese a todo, los géneros menores siguieron gozando de alta consideración como muy adecuados al teatro de urgencia; así, por caso, el de las «Guerrillas del Teatro», en cuyo repertorio no faltaron los entremeses de Cervantes, Quiñones y Calderón ${ }^{24}$. 
Ya en la posguerra la presencia del teatro breve está vinculada a las experiencias teatrales más renovadoras de los grupos independientes y universitarios. Por ejemplo, nos es muy conocido, gracias al esfuerzo de Jesús Rubio Jiménez, el Teatro Español Universitario (TEU) de Zaragoza, en cuya programación la presencia del teatro breve fue constante. Una de las funciones de mayor éxito estuvo constituida, precisamente, por los entremeses de Cervantes, La guarda cuidadosa, La cueva de Salamanca y El viejo celoso, en versión de Alberto Castilla. Castilla, hoy profesor de Literatura en el Mount Holyoke College, ha seguido ocupándose de la dirección de este tipo de espectáculos. En enero de 1995 estrenó en el Teatro Principal de Zaragoza el espectáculo Entremeses del Siglo de Oro, programa que incluía pasos de Lope de Rueda, La elección de los alcaldes de Daganzo y El triunfo de los coches, de Barrionuevo. En programas posteriores, a cargo de otros directores, se incluyeron piezas menos conocidas como La malcontenta, de Luis Quiñones de Benavente. En 1962, bajo la dirección de Juan Antonio Hormigón, se representaron un conjunto de piezas breves a base de dos entremeses de Quiñones de Benavente, El convidado y El médico y el enfermo, el Paso de un ciego, un mozo y un pobre, de Timoneda, El dragoncillo, de Calderón de la Barca, más el Diálogo del amargo, de García Lorca, y la Farsa y licencia del corregidor, de Casona. En 1965 se añadieron al repertorio otros entremeses de Quiñones: Los testimonios de los criados, La melindrosa, El muerto y el soldado, El sueño y el perro, El sacristán y El viejo ahorcado y La manta ${ }^{25}$. La misma apreciación cabe hacer por lo que se refiere al Teatro Universitario de Murcia, donde el teatro breve ocupó un papel muy destacado, gracias al gran conocimiento de la historia teatral del que era y sigue siendo su director, César Oliva ${ }^{26}$.

Los Entremeses de Cervantes suelen ser plato obligado en los repertorios del teatro más avanzado: en 1998 José Luis Gómez realizó una interesante puesta en escena de los Entremeses para su Teatro de la Abadía; al poco, Joan Font, en una versión que debía mucho a la estética de «Comediants» hizo un montaje brillantísimo para la CNTC: el entremés de Los habladores, interpretado en distintos lugares de la sala, servía como hilo conductor de La elección de los alcaldes de Daganzo, La cueva de Salamanca, El retablo de las maravillas y El viejo celoso. Font recalcaba el diseño festivo y lúdico del espectáculo como un modo de trasgresión y no de frívola exhibición, en una especie de viaje «a un mundo fantástico, donde el placer por el juego, la vida y la fiesta, nos transporta a un lugar donde lo lúdico es lo cotidiano y no lo extraordinario en nuestras vidas» ${ }^{27}$. Como se ve, el repertorio cervantino es una y otra vez revisitado, si bien lo es mucho menos el de otros autores. En este senti- 


\section{Algunas reflexiones sobre el teatro breve...}

do, me parece muy de destacar la función que programara en 1995 el director Fernando Urdiales al frente de su «Teatro Corsario». Bajo el título de Clásicos locos incluyó piezas poco conocidas en los escenarios, como La burla del sombrero, de Francisco de Castro, El retrato vivo, de Agustín Moreto, el entremés anónimo de Los sordos, Los poetas locos, de Sebastián de Villaviciosa, y El reloj y figuras de la venta y la mojiganga de Las visiones de la muerte, de Calderón. Un brillante espectáculo en torno -como rezaba el programa de mano- a «una pintoresca galería de figuras agrupadas en torno a enredos de carácter surreal, absurdo, loco, lo que les aproxima a ciertas formas dramáticas contemporáneas como el teatro del absurdo y el teatro dentro del teatro». A veces estas compañías no demasiado profesionalizadas dan un ejemplo de encomiable investigación teatral no conformándose con lo ya conocido y explorando vías nuevas. Aun cuando su difusión fuera muy limitada, otra aventura teatral universitaria digna de ser reseñada fue la Folla a Calderón, que en el $\mathrm{Pa}$ raninfo de la Facultad de Filología de la Universidad Complutense de Madrid representara la compañía «Trujimán», dirigida por Álvaro Tato, a fines de 2000. El provocativo título de la función -buena parte de los espectadores desconocían el significado técnico del término folla- está muy en consonancia con la lectura postmoderna del teatro breve. La folla incluía, junto a piezas musicales del siglo XVII, una Loa basada en el poema autobiográfico de Calderón, "Carta a una dama», la jácara de $E l$ Mellado, y los entremeses de El toreador y El dragoncillo. Son unos pocos ejemplos pero demostrativos del vigor de unos géneros que aún no han exprimido todo su potencial en la escena de hoy.

\section{Claves para una lectura postmoderna del teatro breve clásico}

Es posible que muchas de las apreciaciones que siguen pudieran aplicarse no sólo al teatro breve sino a muchas comedias del siglo XVII. Como arriba quedó dicho, es misión de dramaturgos y directores actualizar los temas, siempre universales, del teatro para ponerlos al servicio de la sociedad actual, siempre, eso sí, que no se cometan desaguisados irreparables, como - por poner un ejemplo calentito- la versión «punki» que del Troilo y Crésida, de Shakespeare, acaba de estrenar Francisco Vidal en la CNTC. Acaso la diferencia entre la comedia y el entremés estribe en que la puesta en escena de este último no exige tantos cortes y manipulaciones como aquella. El público actual parece conectar mejor con el lenguaje desinhibido del entremés que con el de la comedia, lleno de estere- 
otipos sociales a menudo bastante anacrónicos. Mientras que la comedia sigue siendo la gran vedette del espectáculo, y los críticos y los profesores solemos quejarnos -la verdad, sin demasiado fundamento- de cómo se dice el verso y otras cuestiones, el entremés no exige más que un ágil ritmo de representación para captar la atención de un público fácilmente entregado a su espíritu festivo y licencioso. Es el poder de la risa, más universal y duradero que el del llanto, muy acorde con los tiempos postmodernos que corren.. A fin de que pueda verse con claridad este paralelismo entre teatro breve y gusto postmoderno me fijaré en unos pocos componentes ideológicos, a saber ${ }^{28}$.
A) La religión
B) La moral y el sexo
C) $\mathrm{El}$ poder
D) La sociedad
E) La marginalidad
F) El metateatro

\section{A) La religión}

A diferencia de la comedia, en los géneros menores está ausente toda idea de sacralidad y aun yo diría que de Dios mismo. De ahí la sensación de libertad que trascienden las acciones entremesiles, como si procedieran de un mundo donde han desaparecido las presiones y las represiones teológicas. En los entremeses es imposible encontrarse con frases admonitorias del tenor de las que profiere a cada paso el gracioso Catalinón a Don Juan Tenorio en El burlador de Sevilla y que motivan la sarcástica respuesta de éste -«iQué largo me lo fiáis!»-, o la que se convierte en estribillo machacón de $E l$ gran teatro del mundo: «Obrar bien, que Dios es Dios». La ausencia de lo sagrado se complementa, además, con el proverbial anticlericalismo de los entremeses; un anticlericalismo que, si bien es cierto que responde a constantes folclóricas muy arraigadas en el imaginario colectivo, no lo es menos que en el siglo XVI se puso al servicio de la espiritualidad erasmista para atizar a una Iglesia que había perdido el norte evangélico. Como ejemplo, bastaría con acudir al Entremés sin título, de Sebastián de Horozco, en que se presentaba -jante un público de religiosas!- la figura de un Fraile corrupto y mujeriego, que al final es manteado por los mismos personajes que lo han insultado durante la obra.

Después de Trento y con la proscripcion de sacar clérigos a escena, el anticlericalismo del entremés resulta un tanto descafeinado, porque ya no 
Algunas reflexiones sobre el teatro breve...

son curas y frailes los que aparecen sino sacristanes. Para verlo, basta comparar dos piezas breves basadas en el mismo motivo folclórico del estudiante exorcista: El goliardo y el exorcismo, de Hans Sachs, y La cueva de Salamanca, de Cervantes. Mientras que el fastnachtspiel de Sachs surgió dentro de un contexto protestante propicio a la sátira contra el clero católico, el entremés cervantino hubo de convertir al lascivo Cura de la tráadición folclórica en un no menos lascivo Sacristán. Pero, salvada la censura, el efecto en escena es el mismo, pues la indumentaria del sacristán -sotana y bonete- es la misma que la de un cura, al cabo hombres de iglesia los dos. Esta percepción es la que debieron tener los ingenuos aldeanos que, durante una representación de La guarda cuidadosa por «La Barraca", protestaron airadamente el final, que, como se sabe, otorga la victoria al Sotasacristán Pasillas sobre el Soldado en sus pretensiones amatorias sobre la joven Cristina, obligando a variar el desenlace ${ }^{29}$. La máscara del Sacristán sufre curiosas transformaciones en el teatro contemporáneo: pensemos en el Pedro Gailo de Divinas palabras, donde su habitual papel entremesil de amante adúltero es invertido por el de marido cornudo, o el Don Mirlo de La zapatera prodigiosa, este, sí, en su papel de galán.

Desasidos de cualquier miedo escatológico, es el Demonio quien parece presidir las acciones entremesiles, según las denuncias reiteradas que hacen los moralistas del siglo XVII. Un demonio que no sale escaldado, como ocurre en los autos sacramentales y en las comedias de santos, sino triunfante, tal como ocurre en La cueva de Salamanca, de Cervantes, o en $E l$ dragoncillo, de Calderón. Recordemos el célebre pasaje del entremés cervantino, con la ceremonia del conjuro y la aplicación de una ciencia secreta que, sin duda, castigaría la Inquisición:

Estudiante.- La ciencia que aprendí en la cueva de Salamanca, de donde yo soy natural, si se dejara usar sin miedo de la Santa Inquisición, yo sé que cenara y recenara a costa de mis herederos [...]

En fin, este anticlericalismo del entremés clásico pervive en manifestaciones cercanas, como en las obritas de urgencia escritas por Alberti para las «Guerrillas del teatro» (Radio Sevilla), o, en fechas más recientes, en una pieza breve de Domingo Miras, El jarro de plata, programada en TVE hacia 1980, y que originó un escándalo considerable en cierta prensa católica.

B) La moral y el sexo

Como no podía sèr de otro modo, la sexualidad está a flor de piel en los entremeses clásicos, en los que cristaliza una tradición festiva proce- 
dente de la Edad Media. En 1983, bajo el magisterio de Robert Jammes y teniendo siempre como fondo la Floresta de poesías eróticas, redacté un extenso trabajo, "Cómico y femenil bureo», en el que demostraba con abundancia de ejemplos, el latente y patente erotismo del lenguaje entremesil; también, por supuesto, el papel relevante de la mujer, figura demiúrgica de dicho bureo. Algunas colegas feministas, demasiado 'serias' para consagrarse al estudio del teatro clásico, me recriminaron, en el transcurso de las Jornadas de Almagro del año 1987, la sobrevaloración que yo había hecho de ese papel de la mujer, y, como suele decirse, negaron la mayor ${ }^{30}$. Pero los textos $-\mathrm{y}$ no las teorías- cantan, y los entremeses están plagados de frases y declaraciones que no dejan lugar a dudas acerca de la posición privilegiada de la mujer en el entremés. Recuerdo que alegaba yo la valentía y el descaro de aquella moza que, ante las pretensiones de su viejo padre de no dejarla salir de casa acogiéndose al brutal refrán de «la mujer, la pierna quebrada y en casa», se atrevía a descontruirlo replicando: «Eso no haré yo/ aunque me quiebren entrambas». Y claro que al final se salía con la suya, y no tenía que recurrir a situaciones tan extremas como las que nos ejemplifican tantas heroínas del drama barroco, que, viéndose deshonradas y desautorizadas por el padre, han de echarse al monte o directamente en brazos de la muerte.

Pero de vida y no de muerte es de lo que habla el entremés. El dialoguillo que en esa pieza cumbre del arte entremesil que es $\mathrm{El}$ viejo celoso -con escena de cama incluida, si no a la vista, sí a los oídos de los espectadores- sostienen la joven y recatada Lorenza y su sobrina Cristinica, que la espolea al adulterio invitándola a abandonar sus remilgos de conciencia, vale por toda una disertación pesada y aburrida de la moderna teoría feminista:

¿Y la honra, sobrina?

¿Y el holgarse, tía?

¿Y si se sabe?

¿Y si no se sabe?

En definitiva, el entremés se alía con una literatura en la que prima la mirada heterodoxa y diferente: las canciones de malmaridada, las facecias, las novelle, la poesía erótica... Sus autores, fueran misóginos, filóginos o feministas, hacen gala de una sensibilidad pícara y maliciosa, que está a años luz de los condicionamientos morales de otros géneros y que conecta maravillosamente con el gusto posmoderno. 
Algunas reflexiones sobre el teatro breve...

C) $E l$ poder

A donde no se atreve a llegar la comedia se atreve el entremés. Si la figura del rey es intocable en la comedia -salvo en los justificados casos de tiranicidio-, en el entremés simplemente no procede, porque -como escribía Lope en el Arte Nuevo- «entremés de rey jamás se ha visto». Afirmación no del todo cierta para una variante del género difundida a partir de los primeros años del siglo XVII: el entremés burlesco, en el que se ponían en solfa episodios históricos y legendarios, algunos de ellos tan trascendentales para el fortalecimiento de la conciencia nacional como el del Cid. Este tipo de entremés, con su brevedad y su apariencia liviana, es el que abre las espuertas de la parodia desmitificadora, que luego encontraría un género especializado en la comedia burlesca o de disparates $^{31}$, una de las formas más transgresoras del teatro barroco cuando se pone en manos de algún autor tan ácido como el noble abufonado Jerónimo de Cáncer, o en las de un sefardí desterrado en Amsterdam, cual era Manuel de Pina, o, incluso, en las de Calderón (Céfalo y Pocris). En todos estos autores los reyes, bien de Francia, de Castilla o de otros reinos resultan ridiculizados, lo mismo que las convenciones cortesanas, sobre todo a través del lenguaje, de modo que el germen de una forma de teatro moderno como es la parodia (muy del gusto también de la postmodernidad) se encuentra en estas manifestaciones.

Pero fuera de esta variante, el ámbito del entremés está tomado por las clases subalternas. Cada máscara entremesil parece el remedo de un personaje de la comedia: el Vejete es contrafigura del padre de la comedia y, al mismo tiempo, del marido engañado (Cañizares vs. Don Gutierre); la Mujer malmaridada puede obedecer al mismo modelo, pero mientras que en la comedia está abocada a una solución límite (Casandra), en el entremés campa por los terrenos de la amoralidad más alegre; el Soldado es -antes de Valle- un verdadero «Marte de Carnaval» (comparemos El dragoncillo con El alcalde de Zalamea), y el Alcalde es una caricatura del que aparece en la comedia (Pedro Crespo vs. Juan Rana); por otro lado, el villano orgulloso de su condición de cristiano viejo (Juan Labrador, Peribáñez) tiene su réplica en el Bobo, procedente del pastor de las églogas y farsas de fines del siglo XV y primeros años del siglo XVI. Tipo de gran ambigüedad entonces, sirve en ocasiones para la ridiculización de unos modos que Alfredo Hermenegildo identificó en su día plausiblemente con la crítica de los cristianos viejos, aferrados a la cuestión del linaje, que sigue preocupando a lo largo del siglo XVII, como demuestran los hilarantes diálogos de la serie entremesil de Los alcaldes 
490

\section{Javier Huerta Calvo}

encontrados. Su protagonismo en el entremés posterior es indudable, bien en la figura del Simple, tal como lo retratara Lope de Rueda en sus pasos, y sobre todo, en la del Alcalde, figura que, desde el punto de vista ideológico, representa el poder civil, un poder analfabeto, como puede verse en La elección de los alcaldes de Daganzo, donde los pretendientes a la vara de regidor presumen de todo menos de educación y cultura. El citado montaje de La elección de los alcaldes de Daganzo, llevado a cabo por Alberto Castilla con el TEU de Zaragoza, acentuaba los aspectos políticos de este genial entremés: «La plaza de Daganzo, marco de esa 'pequeña Corte' donde ocurre la acción, en la que observamos el tipo de justicia, el sistema de selección para los cargos públicos, la corrupción, la petulancia de gobernantes y gobernados, es parodia de la Corte verdadera y real, en el marco histórico y social de su época» ${ }^{32}$. Por lo demás, en los entremeses de ámbito rural, que son legión, no se practica ese tipo de idealización de la vida campesina según el conocido topos del «menosprecio de corte y alabanza de aldea»; los entremesistas parecen cortesanos convencidos que hablan desde su experiencia urbana, y, por tanto, con un punto de vista más moderno.

\section{D) La marginalidad}

Pero, sin duda, donde la sociedad entremesil muestra un mayor grado de desapego respecto de la que nos ofrece la comedia es en esa proverbial capacidad por abrirse al mundo del hampa. Ningún otro teatro de la época ofrece esta fascinación por los márgenes de la sociedad, hasta el punto de encontrar una forma especializada en el tratamiento de este submundo, la jácara, con su galería de rufos y marcas; una exposición del mundo prostibulario que arranca de La Celestina y llega con fuerza a nuestros días, pues que de estos jaques surgen los posteriores majos, chulos y chulapos que pueblan nuestro teatro breve, desde las jácaras a los sainetes dieciochescos y el género chico. En su sugerente Ensayo sobre el machismo español (1971) el dramaturgo Rodríguez Méndez ha trazado una línea en nuestra historia teatral a base de un personaje, que arrancaría en el Escarramán jacaresco y llegaría al Pichi del cuplé contemporáneo pasando por el Manolo dieciochesco o el Julián, «honrado cajista» de La verbena de la Paloma, para demostrar la pervivencia de una figura muy cara al imaginario teatral español y, más en particular, a su realización madrileña. Madrid, tan central en la vida cultural de la postmodernidad -ahí están las películas de Almodóvar o las comedias de 


\section{Algunas reflexiones sobre el teatro breve...}

Alonso de Santos-, es el núcleo del devenir del teatro breve. Aunque el entremés y el sainete han alcanzado proyección nacional, sobre todo en el área levantina y en la andaluza, su arraigo madrileñista es evidente. Se trata de un madrileñismo que, en sus mejores realizaciones, está exento de todo costumbrismo casticista y que, por eso, llega con fuerza a nuestros días; así en las reóperas de Francisco Nieva, tan deudoras de los entremeses clásicos, y que para mí serían las mejores muestras de un teatro postmoderno, abierto a los mundos suburbiales y hampescos, que tiene su modelo en las jácaras del Siglo de Oro.

\section{E) La metateatralidad}

Finalmente, el teatro breve se muestra ducho en el manejo de uno de los recursos básicos de la dramaturgia moderna: el metateatro. En los bailes, los entremeses y, sobre todo, las loas se convierte en un leit motiv constante. La loa es una derivación del antiguo prólogo, del cual nuestros autores modernistas, en plena tendencia a la reteatralización, supieron sacar un gran partido. Ahí están los casos de Benavente, Valle, Grau, Lorca y otros para demostrarlo. En tiempos más cercanos José Luis Alonso de Santos y José Sanchis Sinisterra han seguido esta misma senda. El primero en una pieza como ;Viva el duque nuestro dueño!, que puede tomarse como un «entremés amplificado y «dignificado» ${ }^{33}$. El segundo, en varias obras como Ñaque, y El canto de la rana, homenaje al gran actor que fuera Cosme Pérez, y que simboliza como ninguno el género entremesil, tal como Antonio de Solís lo certifica en la Loa para la comedia de 'Las amazonas' al adjudicarle el papel de Los Entremeses.

Una verdadera joya del metateatro clásico es la mojiganga de Las visiones de la muerte, de Calderón de la Barca, sin duda una de las más representadas. De 1942 data la que tuvo lugar en el Teatro Español de Madrid; el director, Cayetano Luca de Tena, tuvo la feliz ocurrencia de completar la representación del auto sacramental de El pleito matrimonial del alma y el cuerpo con esta pieza magistral, y en su crónica del estreno, subrayaba Alfredo Marqueríe muy inteligentemente el juego metateatral que suponía la inclusión de la mojiganga: "Como siempre, Cayetano Luca de Tena demostró poseer una atrevida y sugestiva concepción escénica al desmontar a medias, pirandellianamente, el escenario que había servido para la representación del Pleito matrimonial, dio a cortina corrida y con el cascabeleo de una collera la sensación del viaje y del vuelco de la carreta de los faranduleros, y desarrolló ante un gra- 
cioso telón con perspectiva campesina la última parte de la obra» ${ }^{34}$. Cincuenta años después, con motivo de los fastos de 1992 por la capitalidad cultural europea de Madrid, tuvimos oportunidad de ver esta mojiganga dentro de la Fiesta barroca, dirigida por Rafael Pérez Sierra, en un contexto que intentaba reconstruir la espectacularidad de la fiesta sacramental tal como se producía en el siglo XVII, procesión del Corpus incluida.

Los juegos entre pasado y presente, tradición y vanguardia, barroco y postmodernidad nos ofrecen esta rica y variada intertextualidad. Para terminar, me referiré al que considero el drama más atrevido, tanto a nivel formal como temático, de todo el siglo XX: El público, de Lorca. Esta profunda exploración metateatral por los recovecos de una personalidad atormentada, la del Director que no se atreve a representar en escena la verdad del teatro bajo la arena, tiene también su correlato entremesil en la figura del Pastor Bobo encargado de recitar la Loa con que, en mi opinión, debe abrirse la representación. Este personaje primitivo, trasunto del Loco carnavalesco que siempre clama por la verdad, se convierte así en el símbolo de la inocencia necesaria para adentrarse en los abismo del «teatro bajo la arena».

\section{Conclusión}

A través de estas líneas me gustaría haber evidenciado que el entremés, el teatro breve por extensión, se ha ido adaptando, con una capacidad excepcional, a los gustos de las diversas épocas $y$, de modo particular, a los de la cultura postmoderna. De ahí que su aprovechamiento por parte de los directores y los dramaturgos diste mucho todavía de ser satisfactorio. Aun reconociendo la maestría insuperable de Cervantes, no podemos conformarnos con la sola representación de sus entremeses. Quedan muchas otras piezas que, editadas y analizadas ya por la crítica, aguardan su lectura por parte de directores y actores para someterlas añ refrendo, siempre incierto, de las tablas.

\section{Notas}

1 Es evidente que las cosas han cambiado para bien en las aulas universitarias, pese al reciente diagnóstico en contra que daba Juan Goytisolo en su artículo de El País (23V-2004), "Transición, intransición y regresión». Aunque simpaticemos con muchas de las ideas de este que más que enfant es ya parent terrible de nuestra cultura, no podemos 
compartir su visión anacrónica de la universidad y la investigación españolas, que, de hacerle caso, se encontrarían en una lamentable situación regresiva, es decir, casi peor que en tiempos de Franco. Según Goytisolo, en los planes de estudios no aparecen obras fundamentales como el Cancionero de burlas, ni -lo que es más grave-La lozana andaluza. Pues bien, dése una vuelta el autor de Juan sin tierra por las aulas que mejor conozco, las de la Universidad Complutense, y se sorprenderá de que estas obras no sólo figuren en los programas de varias asignaturas, sino de que existan incluso materias específicas como Literatura española y marginalidad, donde se leen y analizan textos como los mencionados y aun más atrevidos. Es curioso, por otro lado, que las argumentaciones de Goytisolo insistan siempre en cierta literatura erótica, judaizante o mudéjar, pero dejen de lado las formas del teatro breve, que están tan próximas a su visión del mundo.

2 Para esta visión telegráfica de la cultura postmoderna sigo la muy útil y clara síntesis de David Lyon, Postmodernidad [1994], trad. Belén Urrutia, Madrid, Alianza, 2000, $2^{\text {a }}$ ed.

3 Por cierto, que Nietzsche se sintió atraído por una forma de teatro breve que fue el género chico, elogiado por él tras presenciar una representación de La Gran Vía en Turín, en 1888. La anécdota, que muchos se limitan a referir sin apoyo documental alguno, está recogida con indicación de su procedencia -el epistolario del filósofo- por Fernando Doménech Rico en su estupenda edición de La zarzuela chica madrileña: La Gran Vía, La verbena de la Paloma, Agua, azucarillos y aguardiente, La Revoltosa, Madrid, Castalia, 1998, p. 34.

${ }_{4}$ Para ver lo que va de ayer a hoy, en cuestiones de gusto historiográfico, se puede comparar el progresivo grado de atención concedido al teatro breve del siglo XVII en algunos manuales ya clásicos: dos páginas en la Historia del teatro español, de Francisco Ruiz Ramón (Madrid, Cátedra, 1979, $1^{\text {a }}$ ed.); un capítulo de nueve páginas en la Historia del teatro en España, dirigida por José María Díez Borque (Madrid, Taurus, 1983); otro capítulo, pero de casi cuarenta páginas, en la Historia del teatro español del siglo XVII, de Ignacio Arellano (Madrid, Cátedra, 1995), y otro largo capítulo de cuarenta páginas aún más densas -debido a la pluma de Abraham Madroñal- en la Historia del teatro es. pañol, dirigida por quien escribe estas líneas (Madrid, Gredos, 2003).

5 Remito al número 639-640 (marzo-abril 2000) de Ínsula, coordinado por mí, donde podrá encontrar el lector una panorámica bastante completa del teatro breve en sus diversas épocas, con el concurso de algunos de los principales investigadores que han destacado en la materia, como Ignacio Arellano, María Luisa Lobato, Héctor Urzáiz, María José Martínez, Fernando Doménech, Alberto Romero, Jesús María Barrajón y Emilio Peral. El lector me disculpará la autocita constante. No se debe, créanme, a ningún narcisismo, sino al carácter sintético de este artículo, en el que vienen a resumirse muchos años de investigación, nada menos que veinticinco, acerca de estos géneros.

${ }^{6}$ Por entonces ya García Lorenzo estaba prestando mucha atención a los géneros menores y, sobre todo, a uno de sus esquejes más interesantes, la comedia burlesca. En relación con los primeros tuvo mucha importancia el encuentro que en 1982 tuvo lugar en la Casa de Velázquez y cuyas actas aparecieron recogidas bajo el título de El teatro menor en España a partir del siglo XVI (Madrid, CSIC/Casa de Velázquez, 1983), donde se hacía un repaso histórico desde el entremés hasta el teatro breve de Lauro Olmo, con aportaciones muy interesantes de Carlos Serrano y Serge Saläun, por lo que hace a la pervivencia de los géneros ínfimos a fines del siglo XIX.

7 Aurora Egido, "Heráclito y Demócrito: imágenes de la mezcla tragicómica», en Teatro español del Siglo de Oro. Teoría y práctica, ed. Christoph Strozetzki, Frankfurt-Madrid, Vervuert-Iberoamericana, 1988, pp. 68-101. 
8 En Bocacio y su época, trad. Luis Pancorbo, Madrid, Alianza, 1975.

9 Para quien no comparta la solemne y estúpida "seriedad" de algunos aburridos teóricos, similares a aquellos gramáticos y retóricos a los que fustigara la Stultitia erasmiana, es absolutamente recomendable la lectura de la novela de David Lodge, Small World, traducida al español como El mundo es un pañuelo.

10 Véase de Javier Huerta Calvo, "Elogio del filólogo extravagante», en Literatura y transgresión. En homenaje al profesor Manuel Ferrer Chivite, Ámsterdam/Nueva York, Rodopi, 2004, pp. 25-37.

11 Véase mi artículo «Lo carnavalesco como categoría poética en la teoría literaria de Mijaíl Bajtín", en Formas carnavalescas en el arte y la literatura (Barcelona: Ediciones del Serbal, 1989), pp. 13-31.

12 Una inteligente interpretación de Bajtín en clave postmoderna puede verse en Iris M. Zavala, La posmodernidad y Mijail Bajtín. Una poética dialógica, trad. Epicteto Díaz Navarro, Madrid, Espasa Calpe, 1991.

13 "La sonrisa de Menipo. El teatro breve de Calderón ante su cuarto centenario", en Estado actual de los estudios calderonianos, ed. Luciano García Lorenzo, Kassel, Festival de Almagro/ Reichenberger, 2000, pp. 99-186.

14 Jornadas de Teatro Clásico Español, Almagro, Ministerio de Cultura,1978, pp. 137-181.

15 Véase mi artículo «Pervivencia de los géneros ínfimos en el teatro español del siglo XX", Primer Acto, 187 (1980-1981), pp. 122-127.

${ }^{16}$ Véase Teatro y Carnaval, número monográfico de Cuadernos de Teatro Clásico, 12 (1999).

17 Véase «La recuperación del entremés y los géneros teatrales menores en el primer tercio del siglo XX", en El teatro en España entre la tradición y la vanguardia, ed. Dru Dougherty y M.F. Vilches de Frutos, Madrid, CSIC/Fundación García Lorca/Tabacalera S.A., 1992, pp.285-294.

18 Con la intención de acoger este magno corpus teatral ha surgido la colección «Teatro Breve Español», de la editorial Iberoamericana. Ha aparecido ya el volumen 1, dedicado al Teatro breve de Luis Vélez de Guevara, en edición de Héctor Urzáiz Tortajada, y está a punto de hacerlo el volumen 2, que recogerá los Entremeses, de Antonio de Zamora, en edición de Rafael Martín Martínez. La intención es seguir con autores de otras épocas, como los hermanos Álvarez Quintero, o Benavente.

19 La perspectiva de la fiesta, esto es, el espectáculo en que se fundían, en un plano de igualdad, comedias y piezas menores, ha ayudado a entender mejor los complejos mecanismos formales e ideológicos de la comedia barroca. Veáse la reconstrucción que de la fiesta sacramental hiciera José María Díez Borque en su edición de La segunda esposa, auto de Calderón, Madrid, Taurus, 1985, o mi edición de Una fiesta burlesca del siglo de oro: Las bodas de Orlando, Viareggio, Mauro Baroni Editore, 1998.

20 La Farsa, 316 (30-IX-1933).

${ }^{21}$ Emilio Peral ha derrochado entusiasmo y sabiduría en la clasificación del ingente material que el teatro breve ofrece a lo largo del siglo XX en su tesis Formas del teatro breve español en el siglo XX (1892-1939), Madrid, Fundación Universitaria Española, 2003. Peral deja a un lado las formas del teatro casticista para concentrarse en las más interesantes, o sea, las de índole carnavalesca, y apunta en el haber de Jacinto Benavente el mérito de ser el primero en reivindicar tales formas y en inaugurar el fascinante itinerario de la farsa en el siglo XX. En la reseña que hiciera de nuestra edición del Teatro 


\section{Algunas reflexiones sobre el teatro breve...}

fantástico (Acotaciones, 9 [2002], pp.168-170) reivindicaba Ignacio Amestoy esta insólita faceta postmoderna de Benavente.

22 Tomo la cita de Francisco García Lorca, Federico y su mundo, ed. Mario Hernández, Madrid, Alianza, 1981, p. 441.

${ }^{23}$ Véase mi artículo "La utopía en escena: el teatro de Alejandro Casona", Actas del Congreso Homenaje a Alejandro Casona (1903-1965). Congreso internacional en el centenario de su nacimiento (Oviedo, 5-8 de noviembre de 2003), Oviedo, Universidad de Oviedo, 2004, en prensa.

24 Para todo ello véase el documentadísimo libro de Robert Marrast, El teatre durant la guerra civil espanyola, Barcelona, Publicacions del Institut del Teatre, 1978.

${ }^{25}$ Véase el artículo de Jesús Rubio Jiménez y Patricia Almárcegui, "El teatro universitario en Zaragoza (1955-1965)», en Teatro universitario en Zaragoza. 1939-1999, ed. Jesús Rubio Jiménez, Zaragoza, Prensas Universitarias de Zaragoza, 1999.

${ }^{26}$ Ocho años de teatro universitario (Teatro Universitario de Murcia, 1967-75), Murcia, Universidad de Murcia, 1975.

27 En La Compañía Nacional de Teatro Clásico, 1986-2002, Cuadernos de Teatro Clásico, 16 (2002), p.183.

${ }^{28}$ Por supuesto, abomino de algunas presentaciones sociológicas que se han hecho del entremés en el sentido de buscar las relaciones entre literatura y sociedad a base de anecdóticos y puntuales planteamientos.

${ }^{29}$ La anécdota es recogida por Francisco García Lorca en el libro dedicado a su hermano, Federico y su mundo, Madrid, Alianza, 1981, p.444.

${ }^{30}$ La pequeña y cordial trifulca está recogida en las actas de aquellas Jornadas: Los géneros menores en el teatro español del Siglo de Oro, ed. Luciano García Lorenzo, Madrid, Ministerio de Cultura, 1988, pp.97-127.

${ }^{31}$ El personaje que dicta la última palabra justa o justiciera en los dramas, desaparece del entremés, mejor dicho, no del todo porque a veces está presente como espectador activo, es decir como personaje reflejado en el espejo del escenario barroco. Véase si no el caso de los entremeses palaciegos, como El toreador, de Calderón, por ejemplo, en que Juan Rana se dirige e interpela al rey formando con él una sucesión de espejos a la manera de Las meninas. Evangelina Rodríguez y Antonio Tordera realizaron un minucioso análisis de este entremés, análogo a otros muchos de ámbito palaciego, en los cuales el rey es una especie de convidado de piedra (La escritura como espejo de Palacio. 'El toreador', de Calderón, Kassel, Reichenberger, 1985).

32 "Mi trabajo en el TEU de Zaragoza», en Teatro universitario en Zaragoza. 1939 1999 , p. 194.

33 Véase la «Introducción» de Margarita Piñero y Eduardo Pérez-Rasilla a su edición de la obra en Madrid, Castalia, 2002.

${ }^{34}$ Desde la jaula de los leones. Memorias y crítica teatral, Madrid, Ediciones Españolas, 1944, pp. 249-250. 